\section{Treasure islands!}

Treasure islands! The first word a verb, its mood imperative; and two articles in this issue provide supporting evidence. One is on the partulid snails of Tahiti, with some species facing extinction; the other is about the population of the Juan Fernandez firecrown on Isla Robinson Crusoe, an area of ecological meltdown.

Such examples suggest that islands are analogous to endangered species. That may seem paradoxical, with over a million islands (the number depending on definition), from Greenland to the four tiny red-mangrove islets in Florida Bay, each about $15 \mathrm{~m}$ across, where E. O. Wilson and Daniel Simberloff tested the theory of island biogeography (Wilson, 1992). But the natural and human communities on many islands face threats to their biological and cultural diversity. Dramatic environmental changes - generally involving simplification and degradation of ecosystems-are caused by invasive species, population growth and side-effects of tourism and industry. These processes also affect continental areas. But the effects are stronger on islands because the boundaries that give each its individuality also cut off lines of retreat; and the sea is a highroad for invaders around the compass. So, of all the species of birds that have become extinct in recorded history, 70 per cent have been island endemics. And many distinctive human communities have disappeared: Tierra del Fuegans, Tasmanians, Easter Islanders, the Guanches of Tenerife, the St Kildans - to take just some better known ones.

Many factors make islands vulnerable: isolation, limited area, poor defences and inbreeding. Yet these are also keys to the richness of islands as natural laboratories giving clues to creation-God's footprints, tracked by Darwin in the Galápagos Islands and by Wallace in Indonesia. Note Wallace's prescient judgment:

... should civilized man ever reach these distant lands (the Aru Islands), and bring moral, intellectual and physical light into the recesses of these virgin forests, we may be sure that he will so disturb the nicely-balanced relation of organic and inorganic nature as to cause the disappearance and finally the extinction of these very beings he alone is fitted to appreciate and enjoy (Wallace, 1857).

As God says in Mark O'Connor's poem The Beginninghis chondrichthyomorphic celebration of biodiversity'... we can use Eden again for the small coral cay in the center' (O'Connor, 1990). The social equivalent of insular speciation is noted by the historian H. E. Maude:
The reason why the Pacific Islands possess such importance to the historian, in common with other students of human society, has, as a matter of fact, little to do with their total area or the aggregate size of their population but rather derives from their geographical fragmentation, which has resulted in the growth of a unique multiplicity of small societies. Scattered over a third of the earth's surface, isolated to a varying degree by the vastly more extensive ocean surrounding them, their inhabitants have evolved over a thousand or more years of occupancy a diverse assemblage of social, economic, religious and political systems, of ideas and values, which make the region in a sense the counterpart of the natural scientist's laboratory (Maude, 1968).

Small islands, island arcs and archipelagoes are good places for work on theoretical issues in biology, ecology and sustainable development, because inputs to island ecosystems can more easily be isolated and measured. The jurisdictional autonomy that many sub-national island territories enjoy can also be an advantage in setting up projects (e.g. decisions are taken in Torshaven, not Copenhagen). Ory $x$ readers will generally know how best they can respond to the call to treasure islands. However, for those whose experience has so far been continental, here are some island websites worth exploring*: the UNEP Island Directory for its list of Islands by Conservation Importance; the Small Island Developing States Network, SIDSNET; Falklands Conservation; the Ascension Island (Darwin Initiative) Turtle project; and, for the island researcher or traveller, the invaluable International Centre for Island Studies website with hotlinks to over 800 other island sites.

Finally, we should treasure with a sharp sense of impending loss the many islands with their human communities and diverse species that may be lost early in the next millennium as a result of the current mortality of many coral systems; and the islands that could disappear if sea levels rise as a result of global warming:

Praising what is lost

Makes the remembrance dear

(William Shakespeare in All's Well That

Ends Well).

Iain Orr

${ }^{*}$ www.unep.ch/islands.html; www.sidsnet.com

www.falklands-nature.demon.co.uk;

www.swansea.ac.uk/turtl and www.merger.demon.co.uk/icis 
References

Maude, H.E. (1968) Of Islands and Men-Studies in Pacific History. Oxford University Press, Melbourne.

O'Connor, M. (1990) Fire-Stick Farming-Selected Poems 1972-90. Hale \& Tremonger, Sydney.

Wallace, A.R. (1869) The Malay Archipelago. 2 vols. Macmillan, London.

Wilson, E.O. (1992) The Life and Death of Species. In The Diversity of Life. Yale University Press, Newhaven, Connecticut.

Iain Orr works on UK Overseas Territories environmental issues in the Foreign and Commonwealth Office's

\section{Corrections}

On page 183 of $\operatorname{Oryx}, 33(2)$, an error occurred in the reference section when two references were elided. The references in question should read: Holway, D.A. (1999) Competitive mechanisms underlying the displacement of native ants by the invasive Argentine ant. Ecology, 80(1), 238-251. Lampo, M. \& De Leo, G.A. (1998) The invasion ecology of the toad Bufo marinus: from South America
Environment, Science and Energy Department. He helped organize a conference on the Overseas Territories at London Zoo on 29-30 June. Anyone wishing to have details of what was discussed at the conference or who has ideas about environmental work in the Overseas Territories should contact him (Tel.: + 44 (0)171 270 2942; Fax: + 44 (0)171 270 4076; E-mail: esed.fco@gtnet.gov.uk); or contact the Chairman of the UK Overseas Territories Conservation Forum, Dr Mike Pienkowski (Tel./Fax: + 44 (0)1733 569325; E-mail: pienkowski@cix.co.uk).

to Australia. Ecological Applications, 8(2), 388-396. Holway (1998) in the text on pages 182 and 183 should read Holway (1999).

Our apologies for any confusion these errors may have caused.

We apologise to Alfried P. Vogler for misspelling his name on page 96 of Oryx 33(2). 